\title{
Reliable Detection for Bean yellow mosaic virus, Canna yellow streak virus, and Canna yellow mottle virus in Canna Varieties with Red Foliage
}

Ravendra P. Chauhan, Hayden F. Hamon, Punsasi Rajakaruna, and Mark A. Webb, Department of Entomology and Plant Pathology, Oklahoma State University, Stillwater 74078; Mark Payton, Department of Statistics, Oklahoma State University, Stillwater 74078; and Jeanmarie Verchot, Department of Entomology and Plant Pathology, Oklahoma State University, Stillwater 74078

\begin{abstract}
Chauhan, R. P., Hamon, H. F., Rajakaruna, P., Webb, M. A., Payton, M., and Verchot, J. 2015. Reliable detection for Bean yellow mosaic virus, Canna yellow streak virus, and Canna yellow mottle virus in canna varieties with red foliage. Plant Dis. 99:188-194.

Cannas grow from rhizomes to produce colorful foliage that ranges from deep burgundy, bronze, green, purple veined, and variegated. Bean yellow mosaic virus (BYMV), Canna yellow streak virus (CaYSV), and Canna yellow mottle virus (CaYMV) are problematic viruses infecting cannas. Their disease characteristics have been reported in green-leaved varieties. This study investigated if rhizome planting stocks can be a source of virus infection. PCR and RT-PCR tests identified BYMV, CaYSV, and CaYMV sequences in 20 canna rhizomes and newly emerging leaves. Immunosorbent electron microscopy tests identified filamentous potyvirus particles in rhizome and leaf tissue. In addition, disease characteristics were examined in a subset of red-leaved varieties 'Australia', 'Burning Ember', and 'Red

Futurity' planted in pots in the greenhouse. Plants were assigned identifying codes, visual disease ratings, and samples were taken for RTPCR and PCR virus detection assays. Statistical analysis was carried out to compare disease ratings with RT-PCR and PCR test results. Visual assessment was found to be not a reliable indicator of virus infection in 'Australia' and 'Burning Ember' plants. 'Red Futurity' produced the most obvious pattern of mosaic disease and virus symptoms were easier to identify in this variety. This study demonstrated that visual assessment was an ineffective method for disease identification for the red-leaved varieties. Growers would be well advised to utilize molecular testing to identify infected plants to aid in the cleanup of the crop.
\end{abstract}

Intensive monoculture of ornamental and crop plants aggravates the epidemic spread of many diseases, among the most important of which are viruses. Vegetative propagation is the most significant means of virus transmission among plants that are propagated by grafting, cuttings, tubers, bulbs, or rhizomes. Vegetative propagation is widely used to produce large numbers of plants to meet the demands of international trade and this can lead to the spread of viruses across national borders. An infected foundation stock has potential to yield infected progeny plants. The strategy for preventing the spread of viruses in progeny plants depends upon the successful integration of several distinct activities. This includes: a) the recognition and characterization of the viruses in the plants, b) the development of reliable indexing methods to identify existing healthy stock, c) the development of techniques to establish clones of virus-free foundation stocks, d) the execution of measures to maintain the health of foundation stocks, and e) assured and effective distribution of their progeny to growers and nurseries (8).

The plant family Cannaceae contains one genus, Canna, which are plants grown from rhizomes. Canna rhizomes and potted plants are distributed worldwide for use in landscape and gardens (3). Cannas have broad foliage that ranges in color from deep burgundy, bronze, green, purple veined, and variegated. Reports of viruses impacting cannas have increased worldwide throughout the last decade. Many distributors discontinued selling certain varieties because they do not have disease-free foundation stocks. Given

Corresponding author: J. Verchot, E-mail: verchot.lubicz@okstate.edu

Accepted for publication 18 August 2014.

http://dx.doi.org/10.1094/PDIS-05-14-0538-RE

(C) 2015 The American Phytopathological Society that cannas are vegetatively propagated and the history of virus transmission by this route, we hypothesized that viruses are present in the rhizomes and emerge in the progeny plant. In this study, we carried out tests to detect viruses in the rhizomes and emerging plants.

There are five viruses known to cause foliar disease in cannas: Bean yellow mosaic virus (BYMV) (also known as Bean virus 2 or Canna mosaic virus) (19), Canna yellow mottle virus (CaYMV), Canna yellow streak virus (CaYSV), Cucumber mosaic virus (CMV), and Tomato aspermy virus (TAV). The most widely described viruses are CaYSV (genus Potyvirus) and CaYMV (genus Badnavirus). Notably, the disease symptoms associated with $\mathrm{CaYSV}$ and CaYMV are described in green-leaved varieties as yellow mosaic, streaks, and necrosis along the veins $(18,22)$, while there is little information about the manifestation of disease in redor bronze-leaved varieties.

This study was undertaken for two reasons: first, to test the hypothesis that potyvirus and badnavirus infection can initiate in rhizomes; and second, to assess the most common disease phenotypes in three red-leaved canna hybrid varieties: 'Australia,' 'Burning Ember,' and 'Red Futurity.' 'Australia' plants are standard size, reaching 4 to 5 feet tall, have deep burgundy foliage, and produce stunning red flowers. 'Australia' foliage is deep burgundy when it emerges and holds its color without fading. 'Red Futurity' is a dwarf variety that reaches 2 to 4 feet tall and has red foliage and scarlet red flowers. 'Burning Ember' is a dwarf variety that reaches 2 to 3 feet tall, produces red/green foliage (that is often described as bronze), and deep orange flowers. The emerging foliage of both 'Red Futurity' and 'Burning Ember' display mixtures of red and green colors. As the leaves expand and mature, the red or bronze colors deepen. These three varieties were chosen to study how virus disease would appear in deep burgundy leaves and in leaves that change their color pattern as they mature. 


\section{Materials and Methods}

Plant material, planting location, and visual assessment of disease. Canna rhizomes were planted in containers in a controlled greenhouse and grown under standard conditions of $12 \mathrm{~h}$ daylight at $28^{\circ} \mathrm{C}$ (3). Each plant was given an identifying code. Visual disease indexing (DI) was conducted between 4 and 6 weeks after planting and numerical values were assigned as follows: 1 is healthy, 2 is discoloration, 3 is interruption of red in veins and/or classic mosaic, and 4 is severe disease and necrosis in the greenhouse $(1,7,9-11,14,17,23)$.

Virus detection by RT-PCR, PCR. Total nucleic acid (TNA) was extracted from leaf and rhizome samples using the Maxwell 16 LEV SimplyRNA Tissue kit (Promega, USA) with some modifications. Leaf $(70 \mathrm{mg})$ or rhizome $(1.0 \mathrm{~g})$ samples were submerged in liquid nitrogen and then ground in $200 \mu \mathrm{l}$ or $1.0 \mathrm{ml}$, respectively, Maxwell Simply RNA Tissue homogenization buffer with $2 \%$ 1-thioglycerol. Extracts were centrifuged at $13,000 \times g$ for $5 \mathrm{~min}$ and then equal volume of lysis buffer was added to each recovered supernatant. This mixture was loaded to Maxwell Robot for further TNA purification. Although the kit recommends DNase treatment, this was excluded in order to recover TNA.

Two step RT-PCR reactions were carried out for the detection of BYMV, CaYSV, CMV, and TAV. cDNA synthesis was carried out using $500 \mathrm{ng}$ of TNA, $100 \mu \mathrm{M}$ random hexamer primers, and the High Capacity cDNA Reverse Transcription kit (Applied Biosystems, USA). For detection of BYMV and CaYSV, PCR amplification was carried out for 35 cycles using GoTaq Flexi DNA Polymerase (Promega, USA) $\left(95^{\circ} \mathrm{C}\right.$ for $60 \mathrm{~s}, 50^{\circ} \mathrm{C}$ for $45 \mathrm{~s}$, and $72^{\circ} \mathrm{C}$ for $60 \mathrm{sec}$ ), with a final extension at $72^{\circ} \mathrm{C}$ for $7 \mathrm{~min}$. For cucumoviruses, we employed a similar program but used an annealing temperature of $40^{\circ} \mathrm{C}$ for $60 \mathrm{~s}$ with a final extension at $72^{\circ} \mathrm{C}$ for $7 \mathrm{~min}$. BYMVspecific primers (BYMV-F: 5'-GTGAATGGA CAATGATGGATG$3^{\prime}$ and BYMV-R: 5'-CACGATTGACATCTC CTGCTG-3') amplified products of $382 \mathrm{bp}$ (20). CaYSV-specific primers (Canna-F1: 5'GATCTAACGCAACATATTCGA AAG-3' and Canna-R2: 5'GATCATCCATCATTACCCAATAC-3') amplified products of 695 bp (14). CMV and TAV were detected using Cucumovirus-genus specific primers CPTALL-3 (5'-GACTGACCA TTTTAGCCG-3') and CPTALL-5 (5'-YASYTTTDRGGTTCAATT CC-3') (2). These primers amplify 938 and 966 bp products corresponding to the CMV and TAV viral coat protein sequences (2).

TNA was used for direct PCR amplification using CaYMV-specific primers CaYMV-3 (5'-GACTTCCTGGGTGCAACAAT-3') and CaYMV-4 (5'-TCTGTGCAATCTTGGCGTAG-3'), which yielded 565 bp PCR product (12). PCR was carried out using one cycle of denaturation at $95^{\circ} \mathrm{C}$ for $5 \mathrm{~min}$ and 35 cycles of PCR amplification $\left(95^{\circ} \mathrm{C}\right.$ for $60 \mathrm{~s}, 60^{\circ} \mathrm{C}$ for $45 \mathrm{~s}, 72^{\circ} \mathrm{C}$ for $\left.60 \mathrm{sec}\right)$, with a final extension at $72^{\circ} \mathrm{C}$ for $7 \mathrm{~min}$.

A subset of PCR products for BYMV, CaYMV, and CaYSV were gel-purified using Wizard SV gel and PCR Clean-Up System (Promega, USA) and ligated in pGEM-T Easy Vector (Promega, USA). Sequencing was carried out using a 3730 DNA Analyzer (Invitrogen, USA). These sequences were compared with GenBank reported genomes for BYMV (NC_003492.1), CaYSV (NC013261.1), and CaYMV (JX570734) using nucleotide BLAST (BLASTn) and protein BLAST (BLASTp).

Electron microscopy. A JEOL JEM-2100 transmission electron microscope with an EDAX Genesis 2000 EDS system (JEOL Ltd.,
Tokyo, Japan) was used. Sap extracts from white meristematic regions of rhizomes or leaves were applied to nickel grids and examined for the presence of virus particles. Particle dimensions were measured to determine if they belonged to the genera $\mathrm{Po}$ tyvirus or Badnavirus. Immunosorbent electron microscopy (ISEM) was carried out using polyclonal antisera that detects all potyviruses (AC Diagnostics) using previously reported procedures $(5,21)$. Images were compiled using Adobe Photoshop CS software (Adobe Systems, San Jose, CA).

Relating visual assessment of disease and diagnostic results. SAS version 9.3 (SAS Institute, Cary, NC) was used for calculating statistical measures to determine the effectiveness of the visual assessment in determining the incidence of disease. Following visual assessment, diagnostic RT-PCR was conducted to identify plants that were healthy or infected with BYMV, CaYSV, and CaYMV (20). The relationship between the disease rating values and the results of the virus detection assays was investigated with sensitivity and specificity calculations on a per variety basis. This analysis facilitated the identification of the most consistent and profound disease phenotypes across plant varieties.

\section{Results}

Naturally occurring virus infection in three canna hybrid varieties. To discover if planting materials may be a source of virus disease, we conducted: a) RT-PCR and PCR to detect plant viruses in the rhizomes and emerging leaves, and b) electron microscopy to view particles in rhizome and leaf sap extracts. These assays confirmed the presence of CaYSV, CaYMV, and BYMV in planting materials and in the foliage that emerges from the rhizomes.

Prior to greenhouse planting, TNA samples from 20 rhizomes of four hybrid varieties (Table 1), 'Australia,' 'Striped Beauty,' 'Red Futurity,' and 'Cleopatra,' were subjected to RT-PCR and PCR detection assays to identify BYMV, CaYSV, CaYMV, CMV, or TAV (18). RT-PCR using virus species-specific primers generated 382-bp products detecting BYMV and 695-bp detecting CaYSV. Since CMV and TAV are both cucumoviruses, we employed genusspecific primers that detected both of these viruses and produced bands of 938 and 966 bp, respectively (2). PCR generated a 565-bp product corresponding to the Badnavirus CaYMV, which has a DNA genome (Fig. 1a). Positive controls for these experiments were TNA extracts from virus-infected leaves.

Of the 20 samples analyzed, BYMV was detected in only one rhizome of 'Red Futurity' and this sample also tested positive for CaYSV (Fig. 1a, Table 1). CaYSV was detected in seven 'Red Futurity' and one 'Striped Beauty' rhizomes (Fig. 1b, Table 1). CaYMV was detected in five 'Australia,' one 'Red Futurity,' one 'Striped Beauty,' and two 'Cleopatra' rhizomes (Fig. 1c, Table 1). We failed to detect CMV or TAV in planting materials by RT-PCR (Table 1).

ISEM was employed to visually identify CaYSV virions in sap extracted from rhizomes and leaves that tested positive by PCR for CaYSV (Fig. 2). Because we lack CaYSV species-specific serum, ISEM was carried out using polyclonal sera that detects a range of potyviruses. Filamentous particles were identified in rhizome and leaf extracts that were not identified in heterologous plant extracts. These particles measured approximately $760 \mathrm{~nm}$ in length and 12 $\mathrm{nm}$ in width (Fig. 2a, b), which is within the expected dimensions of Potyvirus particles.

Table 1. PCR and RT-PCR detection of five viruses in rhizome samples collected from four canna varieties ${ }^{\mathrm{a}}$

\begin{tabular}{|c|c|c|c|c|c|c|c|}
\hline Cultivars & No. of rhizomes & BYMV & CaYSV & CaYMV & $\begin{array}{c}\text { BYMV + } \\
\text { CaYSV }\end{array}$ & $\begin{array}{c}\text { CaYSV + } \\
\text { CaYMV }\end{array}$ & CMV + TAV \\
\hline Australia & 7 & 0 & 0 & 5 & 0 & 0 & 0 \\
\hline Red Futurity & 7 & 1 & 7 & 1 & 1 & 1 & 0 \\
\hline Striped Beauty & 4 & 0 & 1 & 1 & 0 & 1 & 0 \\
\hline Cleopatra & 2 & 0 & 0 & 2 & 0 & 0 & 0 \\
\hline
\end{tabular}

a PCR and RT-PCR was conducted using TNA extracted from twenty rhizomes to detect five viruses. None of the samples produced a band using primers detecting the cucumoviruses (CMV and TAV). One 'Red Futurity' sample tested positive for three viruses, BYMV, CaYSV, and CaYMV. 
CaYMV is a member of the Badnavirus group and is expected to have bacilliform shaped particles of approximately 100 to $130 \times 30$ nm (Fig. 2c). Sap was extracted from rhizomes and leaves that tested positive for CaYMV by PCR, and bacilliform particles of $100 \times 30 \mathrm{~nm}$ were identified by direct electron microscopy observation. Since we lack antisera to CaYMV we could not conduct ISEM to selectively absorb CaYMV particles onto grids; however, the combined evidence of PCR and electron microscopy supports the hypothesis that CaYMV is present in rhizomes as well as leaves. CMV or TAV virions were not detected in planting materials by TEM (Table 1 ).

To gain further evidence that virus is transmitted by vegetative propagation, 736 canna rhizomes belonging to the red leaf varieties 'Australia,' 'Red Futurity,' and 'Burning Ember' were grown for 4 to

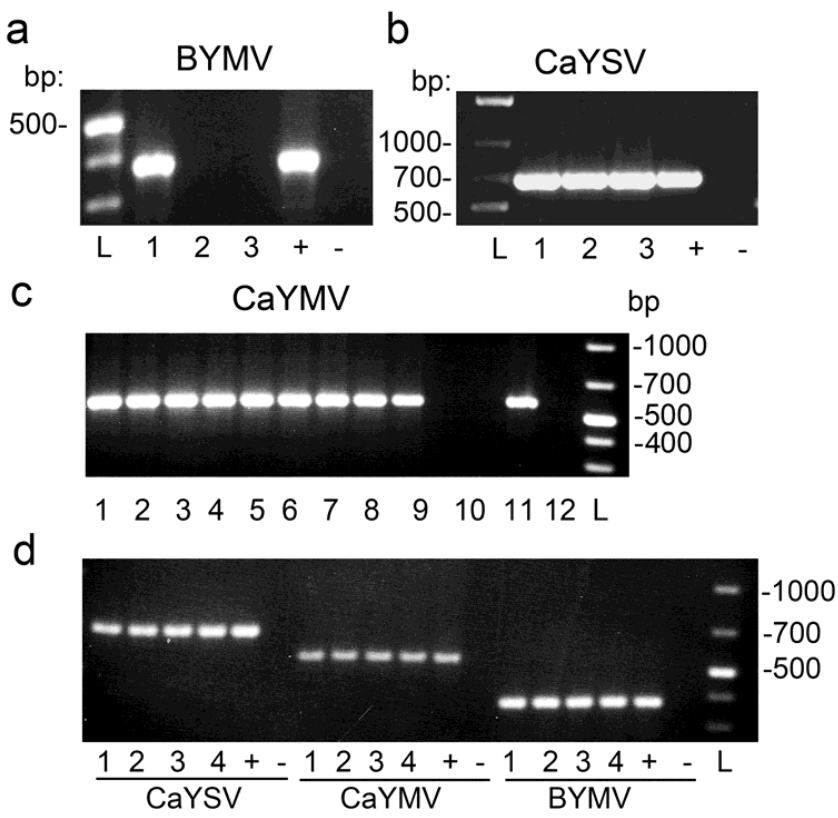

Fig. 1. Ethidium bromide stained gel electrophoresis of $P C R$ products produced using primers that recognize BYMV, CaYSV, and $\operatorname{CaYMV~}(\mathbf{a}, \mathbf{b}, \mathbf{c})$. The viruses identified by PCR are indicated above each panel. 'L' represents the $1 \mathrm{~kb}$ plus ladder. Abbreviations: RF is 'Red Futurity,' Aus is 'Australia,' Cleo is 'Cleopatra,' and SB is 'Striped Beauty.' The PCR products for BYMV were $382 \mathrm{bp}$, CaYSV were 695 $\mathrm{bp}$, and CaYMV were 565 bp in length. (a) Lanes 1, 2, and 3 show the PCR products representing BYMV sequences amplified using TNA from RF236, RF188, and RF238 rhizomes, respectively. Lane 4, a cloned fragment of the BYMV genome, was used as a positive control for PCR. Lane 5, negative control using nuclease free water in place of CDNA for PCR amplification. (b) Lanes 1, 2, and 3 show the PCR products representing CaYSV sequences amplified using TNA from RF236, RF188, and RF238 rhizomes, respectively. Lane 4, a cloned fragment of the CaYSV genome, was used as a positive control for PCR. Lane 5 shows the results of PCR amplification using water in place of CDNA. (c) Lanes 1 to 8 show the PCR products representing CaYMV amplified using TNA from SB44, RF188, Cleo76, Cleo254, Aus24, Aus33, Aus65, and Aus79 rhizomes, respectively. Lanes 9 and 10, CaYMV related PCR products from Aus58 and Aus77 rhizomes. Lane 11, a cloned fragment of the CaYMV genome was used as a positive control. Lane 12, PCR products using water in place of TNA. (d) Representative 382, 565, and 695 bp PCR products amplified and cloned into pGEM-T Easy vector. The sequences of the fragments were compared to reference genomes identified in GenBank and the outcomes are reported in Table 3.
6 weeks and plants were assigned DI values. RT-PCR and PCR virus detection assays were carried out and the outcomes were statistically compared with the visual assessment category (Table 2).

BYMV was detected in four 'Australia,' three 'Red Futurity,' and 27 'Burning Ember' plants. CaYSV was detected in 15 'Australia,' 53 'Red Futurity,' and 27 'Burning Ember' plants. Among the BYMV-positive plants, CaYMV was also detected in the same 'Australia' plants while CaYSV was detected in the same 'Red Futurity' and 'Burning Ember' plants (Table 2). Among CaYSVpositive plants that tested negative for BYMV, 10 'Australia' and two 'Red Futurity' were also infected with CaYMV (Table 2). These combined PCR results suggest that BYMV and CaYSV might occur in mixed infections with each other or CaYMV.

CaYMV was detected in 196 'Australia' $(n=404)$, zero 'Red Futurity,' and four 'Burning Ember' plants. CaYMV sequences have a higher presence in 'Australia,' with $49 \%$ of the plants producing positive PCR results (Table 2) than in other varieties such as 'Red Futurity' and 'Burning Ember'. Only five 'Burning Ember' plants tested positive for cucumovirus. Comparing tables 1 and 2, the cucumoviruses were detected in less than $1 \%$ of the total population of plants or rhizomes analyzed, suggesting that these viruses likely have minimal disease impact on this population of plants.

To confirm that the amplified PCR products correctly identify BYMV, CaYSV, and CaYMV, a subset of PCR products were cloned into plasmids and sequenced (Fig. 1d). Figure 1d shows representative examples of cloned PCR-produced genome fragments of BYMV, CaYSV, and CaYMV. These sequences were compared with the most closely related isolates reported in GenBank using nBLAST (Table 3). For BYMV, CaYSV, and CaYMV, the 382, 695, and 565 bp PCR products, respectively, showed 97 to $99 \%$ identity to the GenBank reported genomes. For BYMV, there were three nucleotide changes that did not result in any amino acid changes in the coat protein. For CaYSV, the PCR products had seven nucleotide changes in the coat protein coding sequence. One nucleotide transversion of $A$ to $G$ changes a codon for isoleucine (ATT) to a codon for valine (GTT) at coat protein nucleotide position 239. There is another single nucleotide transversion that changes a codon for asparagine (AAC) to a codon for serine (AGC) at coat protein nucleotide position 319. All other nucleotide changes are neutral in their impact on the CaYSV coat protein sequence. For CaYMV, the entire viral genome is not sequenced and only a 565-bp fragment of the polyprotein coding region is known. These data support the hypothesis that PCR is an effective
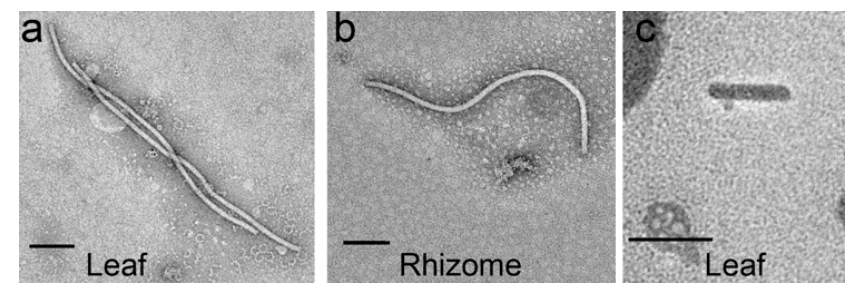

Fig. 2. Electron micrographs of virus-like particles. (a, b) Polyclonal antisera detecting potyviruses was used for ISEM detection of virus particles on a grid. Negative stained flexuous filamentous particles were detected using extracts from leaf and rhizome that tested positive by PCR for CaYSV and CaYMV. (c) Particles that appear to be bacilliform in shape were detected in the same samples. Scale bar equals $100 \mathrm{~nm}$

Table 2. Number plants (\%) which were screened by PCR and RT-PCR for plant virus infection in the foliage of three canna varieties

\begin{tabular}{|c|c|c|c|c|c|c|c|c|c|}
\hline Cultivars & $\begin{array}{l}\text { No. of } \\
\text { plants }\end{array}$ & CaYSV & CaYMV & $\begin{array}{l}\text { CaYSV + } \\
\text { CaYMV }\end{array}$ & BYMV & $\begin{array}{l}\text { BYMV + } \\
\text { CaYMV }\end{array}$ & $\begin{array}{c}\text { BYMV + } \\
\text { CaYSV }\end{array}$ & $\begin{array}{c}\mathrm{CMV}+ \\
\text { TAV }\end{array}$ & $\begin{array}{c}\text { Cucumo + } \\
\text { Potyvirus }\end{array}$ \\
\hline Australia $^{\mathrm{a}}$ & 404 & $15(4 \%)$ & $196(49 \%)$ & $10(3 \%)$ & $4(1 \%)$ & $4(1 \%)$ & $0(0 \%)$ & $0(0 \%)$ & $0(0 \%)$ \\
\hline Red Futurity ${ }^{a}$ & 247 & $53(22)$ & $2(1)$ & $2(1)$ & $3(1)$ & $0(0)$ & $3(1)$ & $0(0)$ & $0(0)$ \\
\hline Burning Ember ${ }^{\mathrm{b}}$ & 85 & $27(32)$ & $4(5)$ & $4(5)$ & $27(32)$ & $3(4)$ & $27(32)$ & $5(6)$ & $1(1)$ \\
\hline
\end{tabular}

a Australia and Red Futurity plants that tested positive for BYMV did not test positive for the cucumoviruses (CMV and TAV).

${ }^{\mathrm{b}}$ Burning Ember plants produced positive results for three and four virus tests. One plant tested positive for BYMV, CaYSV and cucumoviruses. Sequencing was used to confirm that the PCR products belong to either BYMV or CaYSV. Three plants tested positive for all five viruses. 
means to detect BYMV, CaYSV, and CaYMV in samples taken from symptomatic plants.

Characterization of CaYSV and CaYMV disease expression in three canna hybrid varieties. Given that CaYSV and CaYMV were most often detected as mixed or single infections in 'Australia,' 'Red Futurity,' and 'Burning Ember,' we focused our efforts to describe disease phenotypes associated with these two viruses (18). Since BYMV had low occurrence as the sole infecting virus in 'Australia' and 'Red Futurity,' it was not included in this study.

Many 'Australia,' which have deep burgundy leaves, either showed no disease $(\mathrm{DI}=1)$ or mild mottling (DI $=2$ ). It was difficult to be certain if DI $=2$ (Fig. 3) was misassigned to 'Australia' plants that showed normal variation in foliar colors, or was evidence of mild disease or nutritional deficiencies. DI $=3$ was assigned to plants that showed systemic mosaic disease and $\mathrm{DI}=4$ was assigned to individuals showing mosaic and necrosis (Fig. 3).

We compared the RT-PCR and PCR test results with the DI values to identify groups of infected plants that would allow us to make general observations of disease (Table 4). RT-PCR amplified BYMV, CaYSV, or CaYMV in 50\% of the 'Australia' plants tested (Table 4). In Table 4, DI = 1 was assigned to $71 \%$ of the 'Australia' plants identifying these individuals as either uninfected or asymptomatic, while the DI values for $29 \%$ of the plants were 2 or greater. Many 'Australia' plants scored as DI $=1$ tested positive for virus infection, suggesting that they tolerated the presence of virus (Fig. 3). Examples of CaYSV- or CaYMV-infected 'Australia' foliage did not look much different from healthy foliage (Fig. 3). Visual scores of 4 were assigned to 'Australia' plants that had severe discoloration and showed bright yellow streaks in the leaves (Fig. 3). PCR and RT-PCR using the species-specific primers failed to identify virus infection in these plants. These results indicate that a large proportion of plants with this unusual foliar display were either uninfected or infected with an unidentified pathogen, or have a genetic basis for inconsistent leaf pigment patterning.

'Red Futurity' is another dark red leaf variety whose foliage does not have the rich burgundy color or sheen of 'Australia' and the leaves change color patterns as they mature. Young emerging leaves show mixtures of red and green pigments and as the leaf matures, the foliar color becomes uniformly deep red (Fig. 4). The RT-PCR tests revealed that $80 \%$ of the 'Red Futurity' plants con- tained virus (Table 4). Twenty-one percent of the 'Red Futurity' plants were given DI $=1$, suggesting that these plants did not show obvious symptoms, whereas 79\% were given DI values of 2 to 4 . Since similar percentages of plants were identified by visual criteria as well as PCR testing to be virus-infected, the disease indexing method is adequate to distinguish uninfected from infected plants for this variety (Table 4). Healthy or uninfected mature leaves of 'Red Futurity' appeared deep red but when similar aged leaves were infected with CaYSV, they showed bright green streaks and a slight mosaic pattern in the leaf lamina (Fig. 4). Leaves infected with both CaYSV and CaYMV showed green mosaic pattern in the leaf lamina. Both CaYSV and CaYMV appeared to suppress the red pigments in mature leaves (Fig. 4).

'Burning Ember' is sometimes identified as a bronze leaf variety. Close examination of the leaves revealed purple veins and red/green leaf lamina throughout maturity (Fig. 5). Visual assessment of disease in this variety did not assign DI $=1$ and all of the 85 plants were given DI values of 2 to 4 (Table 4), indicating that these plants appeared symptomatic. However, 17 plants in this variety tested negative for viruses by PCR or RT-PCR. The reason is that the green coloration of the leaf lamina is not consistent, and the veins can appear to lose red pigmentation, making it difficult for investigators to objectively identify uninfected and infected plants. Most 'Burning Ember' samples that were virus-infected tested positive for two viruses (Table 2). Single infections were rare in this population. Plants that were infected with CaYSV and/or BYMV showed narrower veins. Red pigmentation was reduced, green color was dull, and mosaic disease occurred on the leaf lamina (Fig. 5).

Interestingly, 'Red Futurity' and 'Burning Ember' plants infected with CaYMV were also infected with CaYSV (Table 2). In general, CaYSV and CaYMV caused mild disease in these red foliar varieties, although they caused severe symptoms on green leaf varieties (18). Leaves infected with both CaYSV and CaYMV show bright green mosaic pattern in the leaf lamina and loss of red pigmentation in the veins in 'Red Futurity' and 'Burning Ember' (Figs. 4 and 5). CaYMV and CaYSV mixed infection was also present in 'Australia' (Table 2), but the deep burgundy color of the foliage makes the plants asymptomatic or tolerant (Fig. 3).

Effectiveness of visual scoring as a diagnosis of disease in these red foliar varieties. A set of visual assessment scores and

Table 3. PCR products amplified using virus-specific primers compared to the reported sequences in GenBank

\begin{tabular}{lccc}
\hline $\begin{array}{l}\text { Name of PCR products cloned } \\
\text { and sequenced }\end{array}$ & $\begin{array}{c}\text { \% nucl. similarity with GenBank } \\
\text { sequences }^{\mathbf{a}}\end{array}$ & $\begin{array}{c}\text { Nucleotide changes/cloned } \\
\text { sequences (bp) }\end{array}$ \\
\hline BYMV - Clone 1 & 382 & 99 & $3 / 382$ \\
BYMV - Clone 2 & 382 & 99 & $3 / 382$ \\
BYMV - Clone 3 & 382 & 99 & $3 / 382$ \\
BYMV - Clone 4 & 382 & 99 & $3 / 382$ \\
CaYSV - Clone 1 & 695 & 98 & $7 / 695$ \\
CaYSV - Clone 2 & 695 & 98 & $7 / 695$ \\
CaYSV - Clone 3 & 695 & 98 & $7 / 695$ \\
CaYSV - Clone 4 & 695 & 98 & $7 / 695$ \\
CaYMV - Clone 1 & 565 & 97 & $13 / 565$ \\
CaYMV - Clone 2 & 565 & 97 & $13 / 565$ \\
CaYMV - Clone 3 & 565 & 97 & $13 / 565$ \\
CaYMV - Clone 4 & 565 & 97 & $13 / 565$ \\
\hline
\end{tabular}

a The nucleotide sequences for PCR products were compared with BYMV (NC_003492), CaYSV (NC_013261), and CaYMV (JX570734) sequences reported in GenBank using BLASTn. For CaYMV, only a $565 \mathrm{nt}$ fragment of the badnavirus polyprotein is reported in GenBank.

${ }^{\mathrm{b}}$ The denominator provides the size of the PCR products that were cloned and sequenced.

Table 4. Total plant population, percent individuals in each DI category, the percent plants identified by PCR to contain virus ${ }^{\mathrm{a}}$

\begin{tabular}{lcccc}
\hline Plant variety & No. of plants ${ }^{\mathbf{b}}$ & \% plants DI = & \% plants DI = 2 to $\mathbf{4}$ & \% $^{\text {plants with virus }}{ }^{\mathbf{c}}$ \\
\hline Australia & 404 & 71 & 29 & 50 \\
Red Futurity & 247 & 21 & 79 & 80 \\
Burning Ember & 85 & 0 & 100 & 67 \\
\hline
\end{tabular}

a Plants were divided into two categories: Those assigned values of DI $=1$ and those assigned values of DI $=2$ to 4 .

${ }^{\mathrm{b}}$ The population of plants is the same as in Table 2 .

${ }^{\text {c }}$ Plants were subjected to RT-PCR or PCR tests using primers to detect BYMV, CaYSV, CaYMV, and cucumoviruses. 
RT-PCR or PCR outcomes for a population of 'Australia,' 'Burning Ember,' and 'Red Futurity' were compared in Table 4 to determine if visual assesment is useful for identifying virus-infected plants. We compared the percentage of plants that were identified by DI = 1 , meaning no symptoms, and the percentage of plants assigned DI $=2,3$, or 4 , meaning minor to severe foliar symptoms or irregularities in color, with the percent of the total plants that tested positive by molecular methods for virus infection. The percentage of 'Australia' plants that tested positive for virus was twice as high as the percentage of plants assigned DI $\geq 2$ (Table 4). The percentage of 'Red Futurity' plants that tested positive for virus and were assigned DI $\geq 2$ were similar, while the percentage of 'Burning Ember' plants that tested positive for virus infection was less than predicted by visual assessment (Table 4). 'Red Futurity' was the one variety for which the DI values, PCR, and RT-PCR results produced the most consistent outcomes. However, for 'Australia' and 'Burning Ember,' the visual assessment of disease was less reliable than molecular methods for identifying virusinfected plants.

To further investigate whether the assigned DI values can be useful for identifying uninfected plants, a second population of plants presented in Table 5 were assigned DI values and then TNA samples were isolated and subjected to RT-PCR or PCR to detect BYMV, CaYSV, CaYMV, and Cucumoviruses. Among 62 'Red Futurity' plants, 12 were assigned DI $=1$ and $42 \%$ of those tested negative for virus infection by PCR. This means that only five of the 12 plants that were predicted to be healthy were in fact virusfree. Similarly, within a population of 210 'Australia' plants, 147 were assigned DI $=1$ and only $55 \%$ of these tested negative for virus infection. For 'Burning Ember,' none of the plants were identified as DI $=1$. These data suggest that plants that appear healthy may be wrongly identified as virus-free if visual assessment is used as the defining criteria (Table 5). Conversely, among all plants assigned DI $\geq 2$, fewer plants were identified by molecular methods to be virus-infected than predicted by the visual rating. Among the 'Red Futurity,' 'Australia,' and 'Burning Ember' plants assigned $\mathrm{DI} \leq 2,17,19$, and $38 \%$ tested positive for virus, suggesting that the low DI values wrongly identified plants as uninfected (Table 5). These data suggest that a commonly used disease indexing system might not be reliable for growers to use to segregate uninfected plants from infected plants.

To determine whether the assigned DI values among the population of plants assessed in Table 5 can be useful for identifying vi- rus-infected plants, we compared $\mathrm{DI}=2,3$, and 4 values to the percentage of plants that tested positive for virus infection. Among the 'Red Futurity,' 'Australia,' and 'Burning Ember' assigned DI > 2, between 62 and $84 \%$ tested positive for virus infection, suggesting that the remaining 16 to $38 \%$ of plants per variety were wrongly identified by visual ratings as infected (Table 5).

If we examine only the plants with DI $\geq 3$, which are predicted to be virus-infected, the molecular diagnostic methods identified
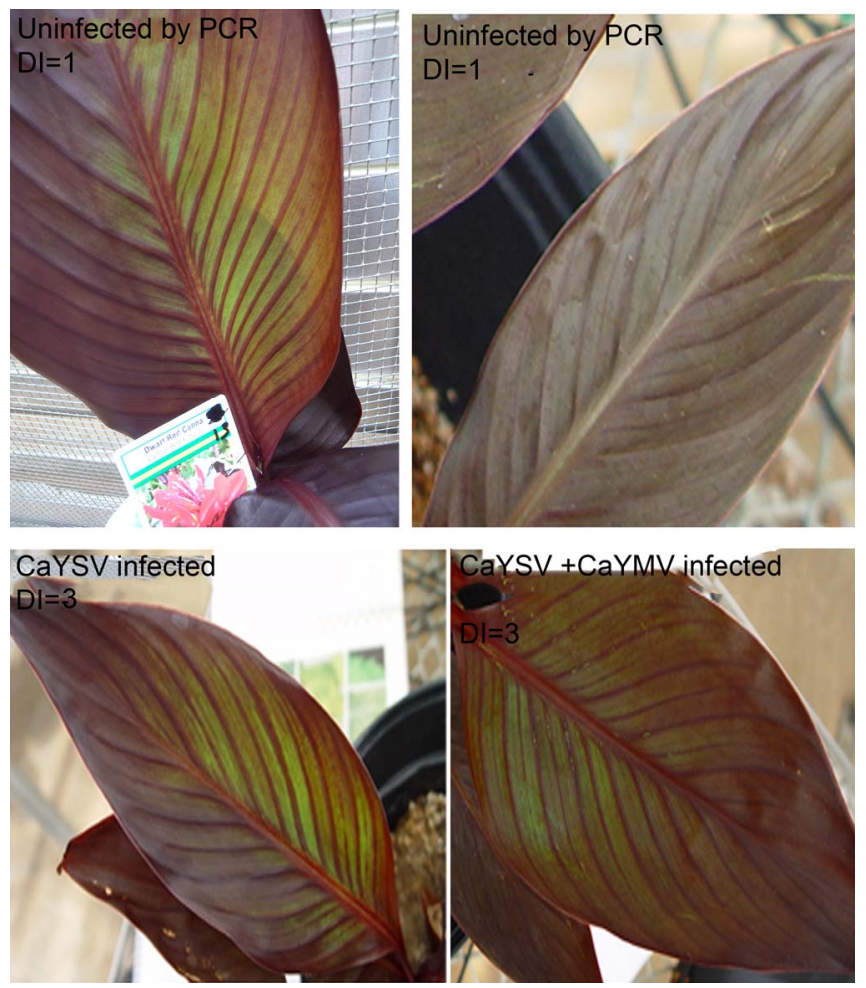

Fig. 4. Healthy and virus-infected 'Red Futurity' plants that are 13 weeks old. We identified plants infected with either CaYSV alone or both CaYSV and CaYMV. CaYSV alone caused bright green streaks in mature leaves. CaYSV and CaYMV mixed infection causes green mottling and interruption of red in veins. Uninfected leaves are red/green. Both CaYSV and CaYMV appeared to suppress the red pigmentation.

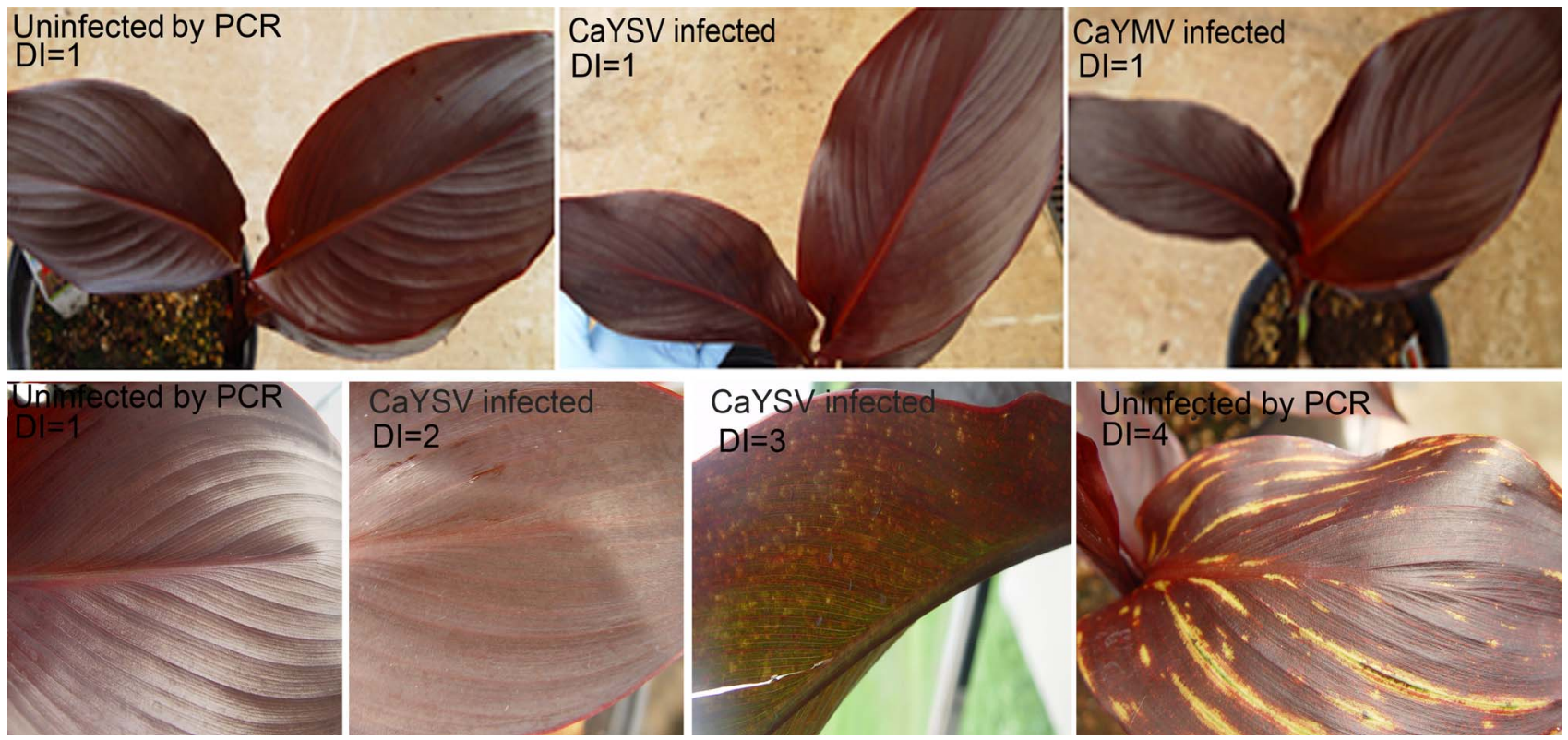

Fig. 3. Healthy and virus-infected 'Australia' plants that are 17 weeks old. CaYSV infected plants show mild discoloration (DI $=2$ ). Plants infected with both CaYSV and CaYMV are asymptomatic. Plants labeled DI = 4 show yellow streaks but tested negative for the five viruses by RT-PCR and PCR. 
between 63 and $78 \%$ to be virus-infected. These data suggest that plants in this category might be infected with a pathogen other than the five known viruses that we tested for, or have uneven foliar colors among individuals within the variety, or nutritionally depleted causes for discoloration that could lead to misdiagnosis of virus infection (Table 5). These data indicate that DI as a sole measurement used to segregate virus-infected red foliar canna plants for discard is not as reliable as molecular diagnostic methods.

\section{Discussion}

Since the discovery of Tulip breaking virus (TBV) and Potato virus $Y$ (PVY), potyviruses have been known to emerge in the foliage from infected planting material (bulbs, rhizomes, and tubers) in vegetatively propagated crops $(6,24)$. In this study, we conducted RT-PCR and PCR to detect plant virus genome sequences in rhizomes and emerging leaves. We also used electron microscopy to identify virion particles in rhizome and leaf sap. Two potyviruses, BYMV and CaYSV, as well as the badnavirus CaYMV were detected by RT-PCR and PCR in rhizomes and emerging leaves of hybrid cannas, suggesting that these viruses are present in planting materials. A larger number of rhizomes $(n=736)$ belonging to three red leaf cultivars were planted in soil and there was a significant percentage of plants whose emerging leaves tested positive for CaYSV, BYMV, and/or CaYMV infection. Electron microscopy also detected filamentous potyvirus virions and bacilliform particles in extracts of canna rhizomes and leaves. The bacilliform particles were approximately $100 \times 30 \mathrm{~nm}$. CaYMV is a pararetrovirus and a member of the genus Badnavirus within the family Caulimoviridae. According to virus taxonomy and classification guidelines set by the International Committee on Taxonomy of Viruses, the virions of both Badnavirus and Tungrovirus, within the Caulimoviridae, are similar bacilliform shaped particles that have a modal length of 100 to $130 \mathrm{~nm} \times 30 \mathrm{~nm}$ (4). Since there is very little known about the genome or virion properties of CaYMV, we cannot conclude from these observations whether these observed particles belong to the genera Badnavirus or Tungrovirus. More in-depth information is needed concerning the distinguishing features of CaYMV such as genome organization and physiochemical properties of the virion to propose an appropriate taxonomic classification. However, the combined data suggests that BYMV, CaYSV, and CaYMV occur in planting materials.

The two cucumoviruses, CMV and TAV, were not detected in rhizomes by RT-PCR and were identified in only $6 \%$ of 'Burning Ember' foliar samples (Tables 1 and 2). In a previous study, approximately $1 \%$ of greenhouse grown plants (11/832) belonging to 24 varieties tested positive by DAS-ELISA for CMV or TAV. In this study, we set aside plants that tested positive by RT-PCR for cucumoviruses and did not sequence the PCR products or pursue studies of this infection, because of their low frequency in large popluations and the lack of evidence that these viruses are transmitted through rhizomes. Another study is needed to focus on the environmental factors that can lead to infection by cucumoviruses, and whether visual inspection can identify these diseases. Comparing the data in this study with prior published results, it appears that CMV and TAV rarely occur in planting materials and are not common disease causing agents in cannas relative to BYMV or CaYSV (18).

RT-PCR and PCR are valuable tools for detecting BYMV, CaYSV, and CaYMV in planting materials and can be used routinely for virus detection to segregate infected and uninfected cannas. Potyviruses are reported to have high variability in coat protein gene, but the high similarity between the BYMV and CaYSV PCR products with related isolates reported in GenBank confirms that the virus-specific primers used in this study reliably detect the target viruses. Although the complete genome of Badnavirus CaYMV is not reported in GenBank, the primers used in this study for CaYMV were found to be reliable for germplasm screening.

BYMV, CaYSV, and CaYMV are reported to cause yellow streaks or yellow mosaic in green leaf varieties $(11,14,17,19)$. In this study, we failed to confirm these disease phenotypes and there may be two explanations. First, we noted that the disease phenotype was difficult to characterize in the red leaf hybrid varieties 'Australia,' 'Burning Ember,' and 'Red Futurity,' and it is likely that the foliar color masks the virus symptoms. The second possiblity is that the viruses studied in Oklahoma are mild strains that cause different diseases from the ones reported in GenBank.
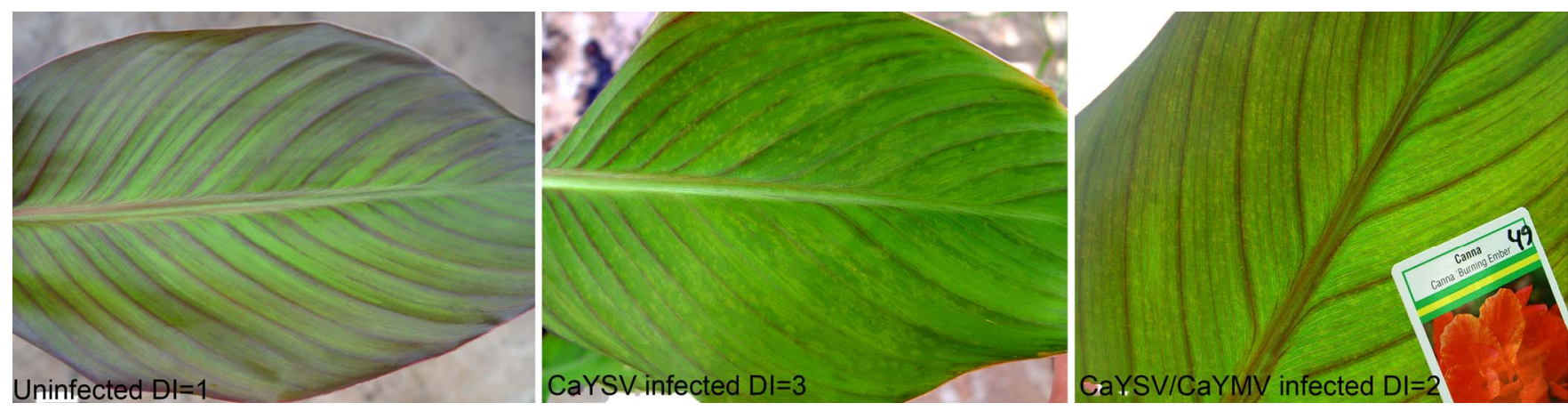

Fig. 5. Images of uninfected and virus-infected 'Burning Ember' leaves that are 8 weeks old. We identified plants that were infected with CaYSV alone or both CaYSV and CaYMV. Both viruses cause mosaic disease and loss of red color in the veins and leaf lamina.

Table 5. Effectiveness of disease indexing (DI) for identifying plants to be virus infected in a subset of plants

\begin{tabular}{lcccccccc}
\hline & $\begin{array}{c}\text { Total no. } \\
\text { plants }^{\mathbf{a}}\end{array}$ & $\begin{array}{c}\text { No. plants } \\
\mathbf{D I}=\mathbf{1}^{\mathbf{b}}\end{array}$ & $\begin{array}{c}\text { \% DI = 1 identified } \\
\text { uninfected by PCR }\end{array}$ & $\begin{array}{c}\text { \% DI } \geq \mathbf{2} \\
\text { identified } \\
\text { infected by PCR }\end{array}$ & $\begin{array}{c}\text { No. plants } \\
\text { DI } \leq \mathbf{2}^{\mathbf{c}}\end{array}$ & $\begin{array}{c}\text { \% DI }<2 \\
\text { identified } \\
\text { infected by PCR }\end{array}$ & $\begin{array}{c}\text { No } \\
\text { plants } \\
\text { DI } \geq \mathbf{3}^{\mathbf{d}}\end{array}$ & $\begin{array}{c}\text { \% DI } \geq \mathbf{3} \\
\text { identified } \\
\text { infected by PCR }\end{array}$ \\
\hline Red Futurity & 62 & 12 & 42 & 84 & 35 & 17 & 27 & 78 \\
Australia & 210 & 147 & 55 & 70 & 166 & 19 & 44 & 73 \\
Burning Ember & 45 & 0 & N/A & 62 & 37 & 38 & 8 & 63 \\
\hline
\end{tabular}

a The total number of plants and the numbers of plants of each variety used in this assessment are listed next to the variety name.

${ }^{\mathrm{b}}$ The number of plants that were assigned DI $=1$, meaning no symptoms, and were tested by RT-PCR or PCR. The $\%$ DI $=1$ identifies the percent of plants that tested negative for virus infection, failing to confirm the visual assessment. The remaining set of plants that were assigned values of $2,3,4$ did not always test positive for virus.

${ }^{c}$ The number of plants that were assigned DI $=1$ or are listed and a percent of these were infected.

$\mathrm{d}$ The number of plants that were assigned DI $=3$ or 4 listed and a percent of these were infected. 
The results of sequencing the PCR products revealed that BYMV had three nucleotide changes that did not cause changes in the amino acid sequence of the coat protein. CaYSV has seven changes in the coat protein that resulted in two amino acid changes. While the sequence results failed to identify changes in BYMV that could impact disease, further investigations are worth examining the relatedness of the entire genome of the CaYSV isolated from cannas in our greenhouse with the GenBank-reported complete genome of an isolate from the United Kingdom (13).

We employed a disease indexing method to identify plants that are healthy, or uninfected by virus, based on methods typically used in agronomically important plants, which are most often green leaf plants $(1,6,9,10,18,23)$. Such a method, if reliable, could be implemented by growers and scientists who want to improve the health of the canna crop. A reliable disease indexing method could enable growers to easily discard infected plants and save healthy ones. To determine our success in identifying virus-infected plants merely by visual inspection, the results of visual DI and laboratory testing were compared in Tables 4 and 5. In general, we found that the DI values did not always correlate with the results of virus detection assays in these varieties. Among plants in Tables 4 and 5 that were assigned DI $=1$, a significant percent of individuals were virus-infected. These data suggest that this visual rating could cause a grower to keep a population of plants that include infected individuals if they do not conduct molecular testing to confirm that these plants are uninfected. This means that visual observations cannot be the sole method to try to eliminate virus from the population.

Conversely, we assessed whether the DI system was useful for identifying infected plants. In Tables 4 and 5, a signficant percent of plants belonging to all three varieties were misidentified as virus-infected. These data demonstrate that it is highly advisable for a grower not to rely solely on visual inspection. In the case of 'Burning Ember,' with 100\% appearing diseased, the entire stock would have been removed and potential erroneous reports of virus infection without proper diagnostics. A significant percent of 'Red Futurity' and 'Australia' plants that were identified as virusinfected by visual means were not infected. These data suggest that there might be other problems occuring in the crop that could be due to other pathogens or nutritional needs. Alternatively, individuals in these varieties might not have consistent foliar colors.

These outcomes are important for scientists to consider in making recommendations to growers. Growers who depend solely upon visual inspection would retain a significant amount of unhealthy plants and could harvest these rhizomes for packaging. Importantly, canna rhizomes after harvest can be divided up to 3fold for propagation. This means that if a grower retains only the DI $=1$ plants and then harvests and divides these rhizomes, it is highly likely that the overall prevalence of disease in the next generation will remain significant. Therefore, the best approach to segregating healthy plants for propagation should include germplasm screening using molecular detection methods.

This report emphasizes that BYMV, CaYSV, and CaYMV can occur in mixed infections. The prevalence of these viruses in a wide range of canna varieties makes it a considerable concern for growers as an emerging disease problem. The presence of viruses in the planting stock might serve as the inoculum for disease spread. Since these viruses are present in the planting stock, a robust germplasm screening program can provide growers with virus-free planting stocks $(15,16)$.

\section{Acknowledgments}

Funding for this project came from the Oklahoma Department of Agriculture, Food, and Forestry (ODAFF) as well as the Oklahoma Center for Advancement in Science and Technology (OCAST) Project number AR11.2-050. We thank Dustin Snow of Horn Canna Farms for additional support for our research. We also thank Dr. Tom Royer of the Department of Entomology \& Plant Pathology, and Dr. Michael Schnelle of the Department of Horticulture and Landscape Architecture for critical review of this manuscript.

\section{Literature Cited}

1. Armitage, C. R., Hunger, R. M., Sherwood, J. L., and Weeks, D. L. 1990. Relationship between development of hard red winter-wheat and expression of resistance to wheat soilborne mosaic-virus. Plant Dis. 74:356-359.

2. Choi, S. K., Choi, J. K., Park, W. M., and Ryu, K. H. 1999. RT-PCR detection and identification of three species of cucumoviruses with a genusspecific single pair of primers. J. Virol. Methods 83:67-73.

3. Cooke, I. 2001. The gardener's guide to growing cannas. Timber Press: David \& Charles, Devon, England.

4. Fauquet, C. M., Mayo, M. A., Maniloff, J., Desselberger, U., and Ball, L. A. 2005. Virus taxonomy. Eighth report of the international committee on taxonomy of viruses. Elsevier Academic Press, San Diego, CA.

5. Goulden, M. G., Kohm, B. A., Santa Cruz, S., Kavanagh, T. A., and Baulcombe, D. C. 1993. A feature of the coat protein of potato virus X affects both induced virus resistance in potato and viral fitness. Virology 197:293-302.

6. Halterman, D., Charkowski, A. O., and Verchot, J. 2012. Potato, viruses, and seed certification in the USA to provide healthy propagated tubers. Pest Technol. 6:1-14.

7. Hayward, K. 2008. Thoughts on virus from hart canna: Canna virus disease. Online: http://cannanews.blogspot.com/2008/01/thoughts-on-virus-fromhart-canna.html, accessed 3 December 2014.

8. Hollings, M. 1965. Disease control through virus free stock. Ann. Rev. Phytopathol. 3:367-396.

9. Hunger, R. M., and Sherwood, J. L. 1985. Use of symptomatology and virus concentration for evaluating resistance to wheat soilborne mosaicvirus. Plant Dis. 69:848-850.

10. Hunger, R. M., and Sherwood, J. L. 1985. Use of visual assessment and elisa to evaluate the reaction of wheat cultivars to wheat soilborne mosaicvirus. Phytopathology 75:964-964.

11. Lockhart, B. 1988. Occurence of Canna yellow mottle virus in North America. Acta Hortic. 234:69-72.

12. Momol, M. T., Lockhart, B. E. L., Dankers, H., and Adkins, S. 2004. Canna yellow mottle virus detected in canna in Florida. Plant Health Progress, doi:10.1094/PHP-2004-0809-01-HN.

13. Monger, W. A., Adams, I. P., Glover, R. H., and Barrett, B. 2010. The complete genome sequence of Canna yellow streak virus. Arch. Virol. 155:1515-1518.

14. Monger, W. A., Harju, V., Skelton, A., Seal, S. E., and Mumford, R. A. 2007. Canna yellow streak virus: a new potyvirus associated with severe streaking symptoms in canna. Arch. Virol. 152:1527-1530.

15. Naik, P. S., Karihaloo, J. L., 2007. Micropropagation for production of quality potato seed in Asia-Pacific. Asia-Pacific Consortium on Agricultural Biotechnology, New Delhi, India.

16. Nolte, P. 2012. Potato seed certification and PVY. Phytopathology 102:149149.

17. Pappu, H., and Druffel, K. 2008. Canna yellow mottle virus in Canna spp. in Washington State. Plant Dis. 92:1136.

18. Rajakaruna, P., Shafiekhani, M., Kim, T., Payton, M., Chauhan, R., and Verchot, J. 2014. Production of discernable disease phenotypes in canna by five plant viruses belonging to the genera Potyvirus, Cucumovirus, and Badnavirus. Plant Pathol. 63:821-830.

19. Skelton, A., Daly, M., Nixon, T., Harju, V., and Mumford, R. 2006. First record of Bean yellow mosaic virus infecting a member of the orchid genus Dactylorhiza. New Dis. Rep. 13:47.

20. Skelton, A., Daly, M., Nixon, T., Harju, V., and Mumford, R. A. 2007. First record of Bean yellow mosaic virus infecting a member of the orchid genus Dactylorhiza. Plant Pathol. 56:344-344.

21. Spillane, C., Verchot, J., Kavanagh, T. A., and Baulcombe, D. C. 1997. Concurrent suppression of virus replication and rescue of movement defective virus in transgenic plants expressing the coat protein of potato virus X. Virology 236:76-84.

22. Verchot, J., and Rajakaruna, P. 2013. Plant viruses infecting cannas. Extension Report EPP-7327, Oklahoma State University, Stillwater.

23. Zhang, D. D., Bai, G. H., Hunger, R. M., Bockus, W. W., Yu, J. M., Carver, B. F., and Brown-Guedira, G. 2011. Association study of resistance to soilborne wheat mosaic virusi in US winter wheat. Phytopathology 101:1322-1329.

24. Zheng, H. Y., Chen, J., Zhao, M. F., Lin, L., Chen, J. P., Antoniw, J. F., and Adams, M. J. 2003. Occurrence and sequences of Lily mottle virus and Lily symptomless virus in plants grown from imported bulbs in Zhejiang province, China. Arch Virol. 148:2419-2428. 